\title{
Correction to: Metallurgical aspects of joining commercially pure titanium to Ti-6Al-4V alloy in a T-joint configuration by laser beam welding
}

\author{
Fedor Fomin ${ }^{1}$ (D) $\cdot$ Martin Froend ${ }^{1,2} \cdot$ Volker Ventzke $^{1} \cdot$ Pedro Alvarez $^{3} \cdot$ Stefan Bauer $^{4} \cdot$ Nikolai Kashaev $^{1}$
}

Published online: 13 August 2018

(C) The Author(s) 2018

\section{Correction to: The International Journal of Advanced Manufacturing Technology \\ https://doi.org/10.1007/s00170-018-1968-z}

The article Metallurgical aspects of joining commercially pure titanium to Ti-6Al-4V alloy in a T-joint configuration by laser beam welding by Fedor Fomin, Martin Froend, Volker Ventzke, Pedro Alvarez, Stefan Bauer and Nikolai Kashaev, was originally published electronically on the publisher's internet portal (currently SpringerLink) on 5 May 2018 without open access.

With the author(s)' decision to opt for Open Choice the copyright of the article changed on 13 August 2018 to (C) The Author(s) 2018 and the article is forthwith distributed under the terms of the Creative Commons Attribution 4.0 International License (http://creativecommons.org/licenses/ by/4.0/), which permits use, duplication, adaptation, distribution and reproduction in any medium or format, as long as you give appropriate credit to the original author(s) and the source, provide a link to the Creative Commons license and indicate if changes were made.

The online version of the original article can be found at https://oi.org/ 10.1007/s00170-018-1968-z

Fedor Fomin

fedor.fomin@hzg.de

1 Helmholtz-Zentrum Geesthacht, Institute of Materials Research, Materials Mechanics, Max-Planck-Straße 1,

21052 Geesthacht, Germany

2 Institute of Product and Process Innovation, Leuphana University of Lüneburg, Volgershall 1, 21339 Lüneburg, Germany

3 Department of Joining Processes, IK4-LORTEK, Technological Centre, Arranomendia Kalea 4a, 20240 Ordizia, Gipuzkoa, Spain

4 Department of Future Industrial System, Airbus Operations GmbH, Airbus-Allee 1, 28199 Bremen, Germany
Open Access This article is distributed under the terms of the Creative Commons Attribution 4.0 International License (http:// creativecommons.org/licenses/by/4.0/), which permits unrestricted use, distribution, and reproduction in any medium, provided you give appropriate credit to the original author(s) and the source, provide a link to the Creative Commons license, and indicate if changes were made. 